Nephron 1991;59:162-163

\title{
Hemodialysis-Induced Hypoxemia and Fibronectin
}

\begin{tabular}{|c|c|c|}
\hline N. & Nurol & Arik \\
\hline $\mathrm{O}$. & Oktay & Özdemir \\
\hline M. & Murat & Sayin \\
\hline T. & Turgay & Arinsoy \\
\hline I. & Izzet & Bariş \\
\hline S. & Semra & Dündar \\
\hline I. & Ilgar & Taşdemir \\
\hline Ç. & Çetin & Turgan \\
\hline Ü. & Ünal & Yasavul \\
\hline Ş. & Şali & Çaḡlar \\
\hline
\end{tabular}

Departments of Nephrology, Hematology and Chest Diseases, Hacettepe University, School of Medicine, Ankara, Turkey

Nurol Arik, MD, Department of Nephrology, Hacettepe University, School of Medicine, 06100 Ankara (Turkey)

FN, mg/l p02 WBC 300

$908580-75-$

280260240220

$200 \mathrm{~J} 70$

Sir,

The pathogenesis of hemodialysis-induced hypoxemia has been debated for many years. Not a single factor was thought to be responsible for hypoxemia during dialysis, instead various causes such as membrane-associated factors [anaphylotoxins and other humoral mediators, 1, 2], respiratory factors [decrease in pulmonary diffusion capacity, 3 , widening of alveolar-arterial oxygen tension gradient, 4 , hypoventilation due to $\mathrm{C} 02$ transfer to acetate dialysate, 5] and pulmonary leukoseques-tration originating from blood-membrane interactions [3] were suggested by several earlier studies. On the other hand, low levels of fibronectin are known to spoil pulmonary gas exchange by elevating the permeability of the pulmonary vessels, thereby leading to pulmonary edema, [6]. In view of the latter information, Schwartz et al. [7] proposed that decreases in plasma fibronectin (FN) levels observed during dialysis can cause dialysis hypoxemia as a result of pulmonary edema in hemodialysis patients.

In order to evaluate the role of FN on the genesis of dialysis hypoxemia, we studied white blood cell counts, arterial blood gases, and FN levels at 0,15,30,60,90 and 120 min during dialysis procedure in 18 patients on maintenance hemodialysis, using a parallel-plate dialyzer with a cuprophane membrane and acetate-buffered dialysate. The results are shown in figure 1. There was a marked drop in leukocyte count at $15 \mathrm{~min}$ and it reached the lowest level at that time. Marked leukopenia was still evident at 30 min of dialysis $(p<0.001)$. Reduction of arterial oxygen tension was 
Time, $\min$

Fig. 1. Changes in laboratory values during hemodialysis.

noted to begin at $15 \mathrm{~min}$ and was most severe at $30 \mathrm{~min}$. The observed hypoxemia lasted during the entire study period $(\mathrm{p}<0.05)$. An early fall in plasma FN levels was observed at $15 \mathrm{~min}$, followed by a return to predialysis levels after $30 \mathrm{~min}$ from the start of dialysis and remained like this through the procedure.

These data indicate that FN may contribute to dialysis hypoxemia only in the early phase of dialysis. The persistence of hypoxemia through the whole course of the study in spite of the normalization of plasma FN levels at 30 min suggested that the factors apart from FN are responsible for dialysis hypoxemia, especially in the late phase of the hemodialysis procedure. Hemodialysis-Induced Hypoxemia and Fibronectin 163

\section{References}

Svenson J, Strandberg K, Tuvema T, Hamberg M: Thrombox-ane A2: Effects on airway and vascular smooth muscle. Prostog-landins 1977;14:425-436.

Adams GK, Lichenstein LM: In vitro studies of antigen-induced bronchospasm: Effect of antihistamine and SRS-A antagonist on response of sensitized guinea pig and human airways to antigen. J Immunol 1979; 122:555.

Craddock PR, Fehr J, Brigham KL, Kronenberg RS, Jacob HS: Complement and leukocytemediated pulmonary dysfunction in hemodialysis. N Engl J Med 1977;296:769-774. Graf H, Stummvoll HK, Haber P, Kovarik J: Pathophysiology of dialysis related hypoxemia. Proc Eur Dial Transplant Assoc 1980;17:155-161.

Sherlock J, Ledwith J, Letteri J: Hypoventilation and hypoxemia during hemodialysis: Reflex response to removal of $\mathrm{C} 02$

across the dialyzer. Trans Am Soc Artif Intern Organs 1977; 23:406-410.

Schumacker PT, Saba TM: Pulmonary gas-exchange abnormalities following intravascular coagulation. Ann Surg 1980; 192:95-98. 